\title{
How Effective are Preconception Care Services for Women with Type 1 or Type 2 Diabetes: A Systematic Review
}

\author{
Karavadra K¹, Gillis RB ${ }^{1,4}$, Jiwani SI ${ }^{1,4}$, Alzahrani ${ }^{1,4}$, Kok S $S^{3,4}$, \\ Harding $\mathrm{SE}^{4}$, Shaw $\mathrm{I}^{2}$ and Adams GG ${ }^{1,4 *}$ \\ 1Faculty of Medicine South Block, Queen's Medical Centre, University of \\ Nottingham, School of Health Sciences, UK
}

2Faculty of Social Sciences, Law and Social Sciences, University Park, University of Nottingham, UK

${ }^{3}$ Department of Food Engineering, Faculty of Engineering \& Architecture, University of AİB, Turkey

${ }^{4}$ University of Nottingham, NCMH Building, Sutton Bonington Campus, Sutton Bonington, Leicestershire, UK

*Corresponding author: Gary G Adams, Faculty of Medicine South Block, Queen's Medical Centre, University of Nottingham, NCMH Building, Sutton Bonington Campus, Sutton Bonington, Leicestershire, LE12 5RD, UK, Email: Gary.adams@nottingham.ac.uk

\section{Abstract}

Introduction: The NICE guidelines provide extensive information on the importance of preconception care for women with type 1 and type 2 diabetes. However, there still remains dispute as to whether it is effective in improving maternal and foetal outcomes. This systematic review aims to establish the effectiveness of preconception care services for women with type 1 and/or type 2 diabetes and to evaluate the factors which prevent women from accessing these services by examining the current primary literature.

Methods: This review involved conducting a thorough electronic search of studies using EMBASE, MEDLINE, CINAHL and grey literature. There was limited research in this area and as such, the main types of studies included were randomised controlled trials, population based studies and perspective cohort studies. The primary outcomes were to assess the level of glycaemic control, the uptake rate of women taking folic acid supplementation and the rate of attendance to preconception clinics.

Results: In total, six studies with a total of two thousand, two hundred and thirty-four participants were included. The studies revealed varying results regarding the relationship between preconception care and overall pregnancy outcomes. Five out of the six included studies showed an overall improvement in glycaemic control. Only three of the studies showed an improved rate in women taking folic acid; whilst only one study stated the neural tube defect rate. The overall patient participation in preconception care services varied amongst studies due to the differences in social demographics of participants.

Conclusions: Preconception care has been noted to improve maternal and foetal outcomes for women with diabetes. The NICE guidelines (2015) have set the standards at which care should be delivered. However the methods in 


\section{Diabetes and Obesity International Journal}

encouraging women from disadvantaged backgrounds needs to be improved. Further qualitative primary research is required to establish how to improve on this and encourage wider participation.

Keywords: Angiotensin; Chorioamnionitis; Risk of Bias; Glycaemic Control; Miscarriage; Folic Acid; Rapid Estimate of Adult Literacy in Medicine (REALM)

\section{Introduction}

There were 2,913,538 people diagnosed with diabetes in England in the year of 2014 [1]. Women accounted for $44 \%$ of people diagnosed with diabetes in 2014 (NICE guidelines, 2015). Some of the main complications of diabetes in pregnancy include; foetal macrosomia, maternal pre-eclampsia, an increased risk of neural tube defects in babies, an increased risk of premature birth and stillbirth [2]. The Confidential Enquiry into Maternal and Child Health (2007) state the importance of preconception care in allowing teratogenic medications to be converted to safer options in pregnancy to prevent congenital malformations (such as stopping angiotensin converting enzyme drugs). Diabetes can also increase the risk of chorioamnionitis (infection within the placental membranes) through premature rupture of membranes and therefore predispose the pregnancy to a pre-term labour [3].

Premature birth is the biggest global killer of young babies, with more than 1 million babies dying each year due to the complications of preterm birth, mostly in the developing world [4]. Compared to Sweden, the primary cause of death in children less than five years of age in the United Kingdom was associated with complications from premature birth [5]. This suggests that primary research is required into how preconception and antenatal care can be further improved in the United Kingdom. Some of the effects of premature birth include; slower physical development, learning difficulties and neurological disorders [6]. These factors alone can affect the quality of life for the baby as well as the parents. For instance, the risk of post-partum depression may be higher in a woman who delivers a baby prematurely.

Women with diabetes are two-to-four times more likely to have a baby with an abnormality and five times as likely to experience a stillbirth compared to without diabetes [7]. Preconception care comprises of three main components: 1) contraception, 2) counselling and 3 ) care [8]. It is essential that diabetic women plan their pregnancy in order to prevent congenital abnormalities [9]. Women are advised to continue using contraception until; they have reached optimal glycaemic control, preconception counselling has occurred and until they have been informed on how to manage diabetes in pregnancy. Some of the medical care includes providing women with folic acid, blood pressure lowering medications and ensuring women are up to date with all vaccinations.

Some of the specific services that preconception care may involve include the following aspects. 1) Facilitating empowerment by providing information to women regarding the risks of pregnancy with diabetes and how these can be reduced. 2) Optimising blood glucose control. 3) Prescribing 5mg folic acid. 4) Changing teratogenic drugs to safer alternatives for use during pregnancy.5) Optimising complications and coexisting medical problems. 6) Supporting weight reduction (if appropriate). 7) Supporting lifestyle changes - such as smoking cessation and considering psychological support [1].

The primary aim of preconception care is to empower women with diabetes to have a positive experience of pregnancy and childbirth by providing information, advice and support that will help to reduce the risks of adverse pregnancy outcomes for the mother and baby [1]. It also aims to plan and set out expectations for the mother during pregnancy and labour [10]. A systematic review carried out by Mills, Palmer and Arya [11] suggested that a multidisciplinary team approach with the woman would help to improve glycaemic control and provide a balanced management plan. As a result this would help promote a healthier pregnancy and reduce the likelihood of diabetes associated complications in pregnancy.

\section{Aim}

The aim of this systematic review is to establish how effective preconception care services are for women with type 1 or type 2 diabetes. The effectiveness of these services can be influenced by many external factors such as social, economic, psychological and cultural factors.

\section{The objectives:}

- To review the current evidence base concerning preconception care.

- To identify effective approaches to reduce complications during pregnancy 
- To identify the social, cultural and economic factors that affect women in seeking preconception care services.

- To address the effectiveness of current preconception care services and how they can be improved.

\section{Methodology}

This review was conducted using the Cochrane handbook of systematic reviews [12] in collaboration with the Prisma guidelines [13]. The purpose of this review was to evaluate the literature around preconception care and diabetes in accordance with the aims and objectives stated below.

\section{Eligibility Criteria}

Included Studies: Randomised control, prospective cohort and population based studies were used in these reviews which were conducted within the last ten years. All studies included were in English language, due to time constraints and difficulty in interpreting them; studies from other languages were excluded. By only including English studies it ensures that there are no misinterpretations of the study's results.
Included Participants: Participants with pre-existing type one or type two diabetes and planning pregnancy or currently pregnant will be included in this review.

Participants with 'gestational diabetes' will be excluded. Due to the nature of the review only women were included however there were no other restrictions to participants.

Included Interventions: The intervention being evaluated was preconception care, therefore the included studies must have had an adequate amount of preconception care. 'Preconception care' includes any type of health intervention in order for the participants to have a healthy and risk free pregnancy. Studies which include women who are not using these services will be excluded.

Included Control Groups: Only studies which included control groups were included in the study, this was to ensure a clear comparison can be made on the effectiveness of preconception care.

Included Outcome Measures: This study required to include information of participants Hba1c levels, number of congenital anomalies or stillbirths and the number of women taking folic acid both with and without intervention.

\begin{tabular}{|c|c|c|}
\hline & Inclusion criteria & Exclusion criteria \\
\hline $\begin{array}{l}\text { Types of } \\
\text { participants }\end{array}$ & $\begin{array}{l}\text { - Women who are pregnant or planning } \\
\text { pregnancy } \\
\text { - No age restriction } \\
\text { - Women with only type } 1 \text { or type } 2 \\
\text { diabetes. }\end{array}$ & $\begin{array}{l}\text { Women with gestational } \\
\text { diabetes were not considered. Women } \\
\text { without type } 1 \text { or type } 2 \text { diabetes were } \\
\text { not considered. }\end{array}$ \\
\hline $\begin{array}{l}\text { Types of } \\
\text { interventions }\end{array}$ & $\begin{array}{l}\text { Preconception care consists of: education } \\
\text { on hba1c levels and over healthy pregnancies, } \\
\text { intake of folic acid and appropriate fluid/diet } \\
\text { intake. }\end{array}$ & \\
\hline $\begin{array}{l}\text { Types of } \\
\text { comparisons }\end{array}$ & $\begin{array}{l}\text { To compare with women who do not } \\
\text { have any type of diabetes or underlying health } \\
\text { condition and ultimately are to have a normal } \\
\text { pregnancy. }\end{array}$ & $\begin{array}{l}\text { - Women that have other health } \\
\text { conditions that may affect maternal and } \\
\text { fetal health. }\end{array}$ \\
\hline $\begin{array}{l}\text { Types of outcome } \\
\text { measures }\end{array}$ & $\begin{array}{l}\text { - Hba1c levels during first trimester of } \\
\text { pregnancy. } \\
\text { - } \quad \text { Number of participants taking folic acid. } \\
\text { - } \quad \text { Number of congenital anomalies. } \\
\text { - } \quad \text { Number of stillbirths. } \\
\text { outcomes. }\end{array}$ & $\begin{array}{l}\text { - Studies which did not focus on } \\
\text { at least one of the stated outcome } \\
\text { measures. }\end{array}$ \\
\hline Types of studies & $\begin{array}{l}\text { - Randomised control studies, prospective } \\
\text { cohort studies and population based studies. } \\
\text { - } \quad \text { Studies which have been published after } \\
\text { January } 2006 . \\
\text { - Studies which have full text available in } \\
\text { English language }\end{array}$ & 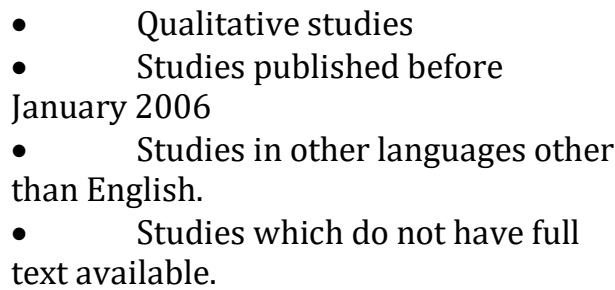 \\
\hline
\end{tabular}

Table 1: Inclusion and exclusion criteria for the identified studies. 
Search Strategy for Included Studies: In order to ensure that there is minimal database bias, the following databases will be included in the search; CINAHL, central database of Cochrane collaboration, Embase and OVID. The databases will be accessed through the University of Nottingham login. The method of hand searching and foot chasing will also be used as this may help to review references of published studies related to the outcome measure.

\begin{tabular}{|c|c|c|c|c|}
\hline \multirow{2}{*}{ S.No } & \multirow{2}{*}{ Search term } & \multicolumn{3}{|c|}{ Number of articles } \\
\cline { 2 - 5 } & & Embase & Medline (Proquest) & Cinahl \\
\hline 1 & Type 1 diabetes & 461 & 1374 & 137 \\
\hline 2 & Type 2 diabetes & 1919 & 7004 & 436 \\
\hline 3 & Glycemic control & 278 & 6917 & 209 \\
\hline 4 & Hb1ac & 964 & 49 & 0 \\
\hline 5 & Preconception care & 7 & 0 & 1 \\
\hline 6 & Prepregnancy care & 3 & 7696 & 555 \\
\hline 7 & 1 or 2 & 2176 & 2670 & 222 \\
\hline 8 & 3 or 4 & 1059 & 8162 & 6 \\
\hline 9 & 5 or 6 & 9 & 34,714 & 5 \\
\hline 10 & 5 or 2 or 1 & 9171 & & 2154 \\
\hline 11 & 7 AND 8 AND 9 AND 1 & 2295 & & 2 \\
\hline
\end{tabular}

Table 2: Table categorizing the number of articles gained from each identified database and the use of Boolean operators to combine each search term (studies included from January 2006 - January 2016).

The literature search was carried out in order of figure 1 where titles and abstracts will be screened for appropriateness and counter checked by a second individual (project supervisor). Those studies which did not appear to be relevant were excluded. The second stage involved all studies which meet the inclusion criteria, full texts were sought to make a final selection. Studies which did not meet the inclusion criteria were to be excluded from the review.

Quality Appraisal: A high quality systematic review provides a comprehensive summary of research-based knowledge on a topic, taking into consideration their quality and validity (DiCenso, Guyatt and Ciliska, 2005). This systematic review will be looking at primary studies of quantitative background. Therefore, emphasis will be placed upon internal and external validity.

Critical Appraisal Tool for Included Studies: Due to the heterogeneity of studies, the Cochrane tool of assessing risk of bias was used. The tool involves assessing each study with either a 'high, low or unclear' risk of bias. The tool allows researchers to interpret which studies are of high quality (with lower risks being better quality).

Data Extraction and Synthesis: The findings of the review are presented using three main themes; attendance to preconception care, intake of folic acid and glycemic control up until the end of the first trimester of pregnancy. A table format has been used to present the findings of each study to allow comparisons to be made.

Ethical Considerations: Although this study did not require ethical approval, each included study was assessed for appropriate ethical consent.

\section{Results}

\section{Database Search Results}

There appeared to be very little research surrounding diabetes and preconception care. However, the initial database search revealed (CINAHL - 245, EMBASE - 48, MEDLINE - 277) studies. Further to this, 728 studies were excluded due to failing to meet the inclusion criteria. Rejected studies included participants, which did not have type 1 or 2 diabetes mellitus, studies which were more than 10 years old and studies which were duplicates. A total of 6 full text articles were taken for further assessment. A thorough search of grey literature and reference list provided 14 additional articles, providing 22 full text articles for examination. The flow diagram in Figure 1 illustrates the study selection/rejection process. Of the 22 full text articles, 6 met the inclusion criteria and were included in this review. 


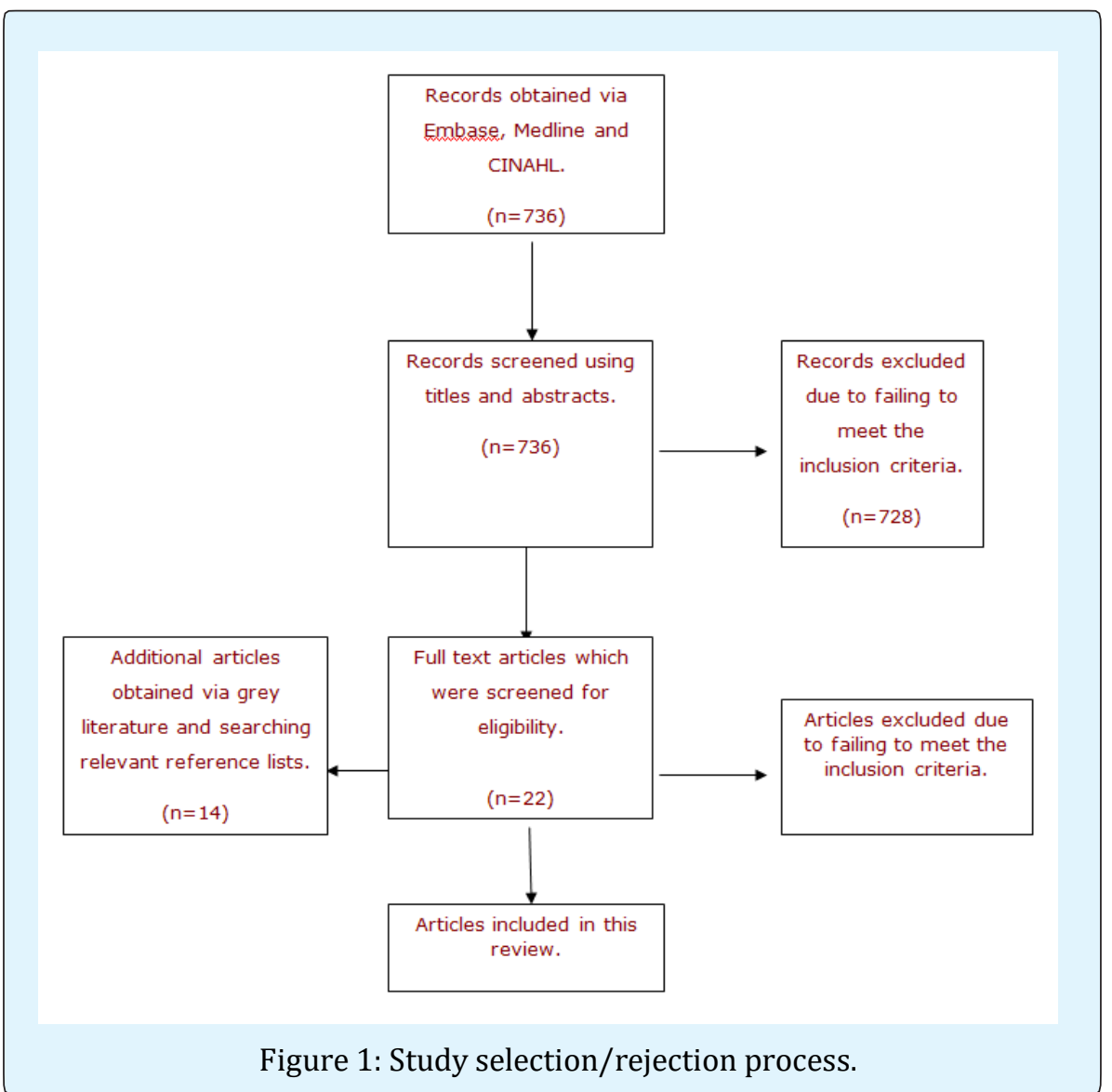

\begin{tabular}{|c|c|c|c|c|c|c|c|c|c|c|c|c|c|c|c|c|c|c|c|}
\hline \multirow{2}{*}{$\begin{array}{l}\text { First } \\
\text { author, } \\
\text { year }\end{array}$} & \multirow{2}{*}{ puration } & \multirow{2}{*}{ Country } & \multirow[t]{2}{*}{$\begin{array}{c}\text { Number of } \\
\text { participants }\end{array}$} & \multirow[t]{2}{*}{\begin{tabular}{|l|} 
Number of \\
women \\
receiving PCC \\
vs No PCC \\
\end{tabular}} & \multicolumn{3}{|c|}{$\begin{array}{c}\text { Percentage of } \\
\text { participants with } \\
\text { mean } \mathrm{HbA} 1 \mathrm{c}<7 \%\end{array}$} & \multicolumn{3}{|c|}{$\begin{array}{c}\text { Percentage of } \\
\text { participants taking Folic } \\
\text { acid. }\end{array}$} & \multicolumn{3}{|c|}{$\begin{array}{c}\text { Number of congenital } \\
\text { Anomalies/ } \\
\text { malformations. }\end{array}$} & \multicolumn{3}{|c|}{$\begin{array}{l}\text { Number of } \\
\text { stillbirths. }\end{array}$} & \multicolumn{3}{|c|}{$\begin{array}{l}\text { Number of } \\
\text { neural tube } \\
\text { defect rates }\end{array}$} \\
\hline & & & & & I & $\mathrm{C}$ & $\begin{array}{l}\text { Group } \\
\text { effect }\end{array}$ & I & $\mathrm{C}$ & Group effect & I & $\mathrm{C}$ & Group effect & I & $\mathrm{C}$ & $\begin{array}{l}\text { Group } \\
\text { effect }\end{array}$ & I & $\mathrm{C}$ & $\begin{array}{l}\text { Group } \\
\text { effect }\end{array}$ \\
\hline $\begin{array}{c}\text { Tripathi, } \\
2010 \text { [14] }\end{array}$ & 3 years & UK & 588 women & 325 vs 297 & $\begin{array}{c}55.40 \\
\%\end{array}$ & $\begin{array}{c}44.60 \\
\%\end{array}$ & $\begin{array}{c}\mathrm{P}=0.001 \\
\%\end{array}$ & $68 \%$ & $31 \%$ & $\mathrm{P}=0.001$ & NR & NR & NR & NR & NR & NR & NR & NR & NR \\
\hline $\begin{array}{c}\text { Holmes, } \\
2016 \text { [15] }\end{array}$ & 4 years & UK & 307 women & 193 vs 114 & $37 \%$ & $39 \%$ & NS & $81 \%$ & $43 \%$ & NS & NR & NR & NR & NR & NR & NR & NR & NR & NR \\
\hline $\begin{array}{c}\text { Callec, } \\
2010[16]\end{array}$ & 8 years & France & 97 women & 97 & NR & NR & NR & NR & NR & NR & 6 & 0 & $\mathrm{P}=<0.00001$ & NR & NR & NR & NR & NR & NR \\
\hline $\begin{array}{c}\text { Temple, } \\
2006 \text { [17] }\end{array}$ & 11 years & UK & 290 women & 110 vs 180 & $62 \%$ & \begin{tabular}{|c|}
35.40 \\
$\%$
\end{tabular} & $\mathrm{P}=0.001$ & NR & NR & NR & 2 & 11 & $\mathrm{P}=0.065$ & 1 & 5 & NS & 6 & NR & NR \\
\hline $\begin{array}{c}\text { Owens, } \\
2012 \text { [18] }\end{array}$ & 6 years & UK & 272 women & 168 vs 104 & $48 \%$ & $63 \%$ & $\mathrm{P}=0.004$ & 41 & 62 & $\mathrm{P}=0.0001$ & 22 & 8 & $\mathrm{P}=0.0001$ & 4 & 1 & $\begin{array}{c}\mathrm{P}= \\
0.0001 \\
\end{array}$ & NR & NR & NR \\
\hline $\begin{array}{c}\text { Murphy, } \\
2010 \text { [19] }\end{array}$ & 3 years & UK & 680 women & 181 vs 499 & $53 \%$ & $77 \%$ & $\mathrm{P}=0.004$ & $\begin{array}{c}88.20 \\
\%\end{array}$ & \begin{tabular}{|c|}
26.70 \\
$\%$
\end{tabular} & $\begin{array}{c}\mathrm{P}= \\
<0.0001\end{array}$ & 0 & 10 & $\mathrm{P}=0.02$ & 1 & 6 & $\mathrm{P}=0.7$ & NR & NR & NR \\
\hline
\end{tabular}

Table 3: Table to show a summary of the main findings from the studies (1).

\begin{tabular}{|c|c|c|c|c|c|c|c|c|c|c|c|c|c|c|c|c|c|c|}
\hline \multirow{2}{*}{$\begin{array}{l}\text { First author, } \\
\text { year }\end{array}$} & \multicolumn{3}{|c|}{$\begin{array}{l}\text { Number of babies } \\
\text { with macrosomia }\end{array}$} & \multicolumn{3}{|c|}{$\begin{array}{c}\text { Number of } \\
\text { premature births. }\end{array}$} & \multicolumn{3}{|c|}{$\begin{array}{l}\text { Number of } \\
\text { women with pre- } \\
\text { eclampsia }\end{array}$} & \multicolumn{3}{|c|}{$\begin{array}{l}\text { Number of women } \\
\text { who experienced a } \\
\text { miscarriage }\end{array}$} & \multicolumn{3}{|c|}{$\begin{array}{c}\text { Number of white British/Irish/ } \\
\text { European women receiving PCC vs non- } \\
\text { white British/European }\end{array}$} & \multicolumn{3}{|c|}{$\begin{array}{c}\text { Number of type } 1 \text { diabetic } \\
\text { women vs } \\
\text { Type } 2 \text { diabetic }\end{array}$} \\
\hline & I & $\mathrm{C}$ & $\begin{array}{l}\text { Group } \\
\text { effect }\end{array}$ & I & $\mathrm{C}$ & $\begin{array}{l}\text { Group } \\
\text { effect }\end{array}$ & I & $\mathrm{C}$ & $\begin{array}{l}\text { Group } \\
\text { effect }\end{array}$ & I & $\mathrm{C}$ & Group effect & I & $\mathrm{C}$ & Group effect & I & $\mathrm{C}$ & $\begin{array}{l}\text { Group } \\
\text { effect }\end{array}$ \\
\hline $\begin{array}{l}\text { Tripathi, } \\
2010 \text { [14] }\end{array}$ & NR & NR & NR & NR & $\mathrm{NR}$ & NR & NR & NR & NR & NR & NR & NR & 229 vs 11 & 265 Vs 32 & $\mathrm{P}=0.011$ & $\begin{array}{c}202 \text { vs } \\
37\end{array}$ & $\begin{array}{c}215 \mathrm{vs} \\
82\end{array}$ & $\begin{array}{c}P= \\
0.014\end{array}$ \\
\hline $\begin{array}{l}\text { Holmes, } \\
2016 \text { [15] }\end{array}$ & 26 & 13 & $\mathrm{P}=0.15$ & NR & $\mathrm{NR}$ & NR & NR & NR & NR & 6 & 16 & $\mathrm{P}=0.01$ & 129 vs 6 & 111 vs 3 & $\mathrm{P}=1.00$ & $\begin{array}{c}95 \text { vs } \\
40\end{array}$ & $\begin{array}{c}88 \text { vs } \\
26\end{array}$ & $\begin{array}{c}P= \\
0.16\end{array}$ \\
\hline $\begin{array}{c}\text { Callec, } \\
2010[16]\end{array}$ & NR & NR & NR & NR & $\mathrm{NR}$ & NR & NR & NR & NR & NR & NR & NR & NR & NR & NR & NR & NR & NR \\
\hline
\end{tabular}




\section{Diabetes and Obesity International Journal}

\begin{tabular}{|c|c|c|c|c|c|c|c|c|c|c|c|c|c|c|c|c|c|c|}
\hline $\begin{array}{c}\text { Temple, } \\
2006 \text { [17] }\end{array}$ & 48 & 78 & NS & NR & NR & NR & 14 & 23 & NS & NR & NR & NR & $\mathrm{NR}$ & NR & NR & NR & NR & NR \\
\hline $\begin{array}{c}\text { Owens, } \\
2012 \text { [18] }\end{array}$ & NR & $\mathrm{NR}$ & NR & NR & $\mathrm{NR}$ & NR & NS & NS & NS & 8 & 22 & $\mathrm{P}=0.001$ & NR & NR & NR & NR & NR & NR \\
\hline $\begin{array}{l}\text { Murphy, } \\
2010 \text { [19] }\end{array}$ & NR & $\mathrm{NR}$ & NR & NR & $\mathrm{NR}$ & NR & $\mathrm{NR}$ & $\mathrm{NR}$ & NR & 28 & 71 & $\mathrm{P}=0.9$ & 166 vs 15 & 387 vs 112 & $P=0.0005$ & NR & NR & NR \\
\hline
\end{tabular}

Table 4: Table to show a summary of the main findings from the studies (2).

\begin{tabular}{|c|c|c|c|}
\hline $\begin{array}{l}\text { First author, } \\
\text { year }\end{array}$ & $\begin{array}{c}\text { Frequency of } \\
\text { preconception } \\
\text { care } \\
\text { intervention/s }\end{array}$ & $\begin{array}{l}\text { Method of delivering } \\
\text { preconception care }\end{array}$ & $\begin{array}{l}\text { Method of assessing the effectiveness of } \\
\text { preconception care }\end{array}$ \\
\hline $\begin{array}{c}\text { Tripathi, } 2010 \\
{[14]}\end{array}$ & Every 4 weeks & $\begin{array}{c}\text { Data obtained from a research } \\
\text { Centre which health outcomes } \\
\text { of women with and without } \\
\text { preconception care. }\end{array}$ & $\begin{array}{l}\text { The level of glycaemic control Intake of } \\
\text { folic acid } \\
\text { The reduced risk of pregnancy outcomes. }\end{array}$ \\
\hline $\begin{array}{c}\text { Holmes, } 2016 \\
{[15]}\end{array}$ & Every 2-6 weeks & $\begin{array}{l}\text { A preconception counselling } \\
\text { DVD and preconception clinic } \\
\text { appointments. }\end{array}$ & $\begin{array}{l}\text { Mean HbA1c during first trimester. } \\
\text { Number of women taking folic acid during } \\
\text { conception. }\end{array}$ \\
\hline Callec, 2010 [16] & Every 4-12 weeks & $\begin{array}{c}\text { Physician consultations } \\
\text { Replacement of anti-diabetic } \\
\text { drugs with insulin Education to } \\
\text { maintain HbA1c levels }<6.5 \% \\
\text { during conception. }\end{array}$ & $\begin{array}{l}\text { Rate of fetal malformations in type } 2 \\
\text { diabetic women in comparison to type } 1 \\
\text { diabetic women. }\end{array}$ \\
\hline $\begin{array}{c}\text { Temple, } 2006 \\
{[17]}\end{array}$ & Every 1-3 months & $\begin{array}{l}\text { Diabetic clinics with specialist } \\
\text { nurse and consultant physician. } \\
\text { Patient education on the } \\
\text { consumption of folic acid } \\
\text { supplements and maintaining } \\
\text { HbA1c levels. }\end{array}$ & $\begin{array}{l}\text { Rate of congenital malformations. The } \\
\text { number of stillbirths. Complications in } \\
\text { pregnancy such as severe hypoglycaemia } \\
\text { and spontaneous abortions. The rate of } \\
\text { premature delivery. The rate of } \\
\text { Macrosomia and preeclampsia }\end{array}$ \\
\hline Jwens, 2012 [18] & Every 4 weeks & $\begin{array}{l}\text { Preconception clinic which } \\
\text { consisted of specialist diabetic } \\
\text { and obstetric staff. Clinics } \\
\text { consisted of patient education, } \\
\text { contraceptive advice, provision } \\
\text { of folic acid, } \\
\text { initiation/intensification of } \\
\text { insulin, prevention and } \\
\text { treatment of hypoglycemia and } \\
\text { discontinuation of teratogenic } \\
\text { drugs. }\end{array}$ & $\begin{array}{l}\text { Rates of minor and major congenital } \\
\text { anomalies. Preeclampsia rates Caesarean } \\
\text { section and stillbirth rate. }\end{array}$ \\
\hline $\begin{array}{l}\text { Murphy, } 2010 \\
\text { [19] }\end{array}$ & Every 4-6 weeks & $\begin{array}{l}\text { Preconception and pregnancy } \\
\text { care program in maternity units } \\
\text { located regionally. }\end{array}$ & $\begin{array}{c}\text { The level of glycaemic control Intake of } \\
\text { folic acid and reduced risk of pregnancy } \\
\text { outcomes. }\end{array}$ \\
\hline
\end{tabular}

Table 5: Table to show the methodological summary for each included study.

\section{Included Studies}

A total of 6 studies were included in this review, a summary of each study can be found in tables 3,4 and 5 . The included studies either focused on maternal and foetal outcomes and participant demographics. Each study focused on at least one of the above key themes. However as previously stated, preconception care in diabetes is an area of research which lacks in depth findings based on the primary literature search.
Therefore, it proved difficult to obtain studies which included all of the key themes.

Theme 1-Glycemic Control in First Trimester: All included studies looked at HbA1c levels during the first trimester of pregnancy or preconception. Table 3 shows the mean \% (mmol) of HbA1c of included participants. All six studies showed a positive relationship between pre-pregnancy care and a decreased $\mathrm{HbA1c}$ level during the first trimester. $\mathrm{HbA} 1 \mathrm{c}$ has been referred to in the 


\section{Diabetes and Obesity International Journal}

form of a sufficient (with a value around $7 \mathrm{mmol} \%$ ) or insufficient (significantly over $7 \mathrm{mmol} \%$ ) value) [1].

Tripathi [14] explored 588 women with diabetes and found preconception counseling was significantly associated with better glycemic control. There were 240 women who received preconception care from which 51 of these women had an HbA1c $<7 \%$ and 109 women had an HbA1c $>7 \%$. In comparison to this, 297 women did not receive preconception care from which 29 of these had an HbA1c of $<7 \%$ and 117 who had an HbA1c $>7 \%$. However, data regarding the HbA1c level was missing for 276 women accounting for $47 \%$ of the sample of the study.

Owens [18] examined 272 women and found that glycemic control improved for women with both type 1 and 2 diabetes mellitus. There were $61 \%$ of these women who had type 1 diabetes and $39 \%$ who had type 2 diabetes. The overall initial HbA1c value decreased from 7.3 to $6.9 \%$ and the number of women achieving HbA1c under $<7 \%$ during their initial assessment increased significantly. Women with type 1 diabetes during the period of 2005-2007 achieved a mean HbA1c of $7.9 \%$ and $7.6 \%$ during $2008-2010$. Women with type 2 diabetes mellitus during the period 2005- 2007 7.7\% and 7.1 during 2008-2010. Similarly, Callec, Galet, Morel et al. [16] carried out an observational study using a total of 97 women with type 2 diabetes mellitus. The mean HbA1c during the first trimester of pregnancy was $7.23 \%$ and at the end of the pregnancy was $6.07 \%$. There were up to $25 \%$ of women, who did not receive preconception care and had an HbA1c level of up to $8 \%$. It was found that women who received preconception care had lower HbA1c levels in later part of their pregnancy.

Temple, Aldridge and Murphy [17] used a prospective observational cohort study of 290 women with type 1 diabetes. Two women declined to be part of the study. A total of 110 women received pre-pregnancy care at a clinic. At an initial pregnancy clinic visit $82.7 \%$ of women with pre-pregnancy care had an HbA1c $<7.5 \%$ and $62.7 \%$ had an HbA1c of $7 \%$. In comparison to this $50 \%$ of women who did not receive prepregnancy care had an HbA1c of $<7.5 \%$ and $35.4 \%<7 \%$. It was found that women who attended pre-pregnancy care programs had a mean HbA1c of $5.9 \%$ in comparison to $6.6 \%$ to women that did not attend prepregnancy care. However there was no evidence of significant difference in the incidence of hypoglycemia between women who did and did not receive preconception care.

Murphy, Roland, Skinner, et al. [19] used a prospective cohort study in 680 women with type 1 and type 2 diabetes. A total of 181 (27\%) women attended preconception care and 499 (73\%) women did not. It showed $53 \%$ of the intervention group receiving preconception care had maintained HbA1c levels below $7 \%$. For women with type 1 diabetes their glycemic control was better in comparison to type 2 diabetes. A prospective population based study by Holmes, Hamill, Alderdice, et al. [15] included 249 women of which 135 were post intervention and 114 pre-intervention. There were 183 women who had type 1 diabetes and 66 with type 2 diabetes. In addition to this $37 \%$ of the preintervention group had an HbA1c $<7 \%$ compared to $39 \%$ in the post intervention group. The study showed the post intervention group to have a lower HbA1c at the first clinic visit ( $6.9 \%$ vs $7.8 \%$ ) in comparison to the group with no intervention. Although despite this, the overall difference in the average HbA1c level in the first trimester was not as significant ( $7.4 \%$ vs $7.3 \%$ ).

Theme 2-Intake of Folic Acid: Four studies found an increase in women taking folic acid after preconception care. One study did not investigate folic acid. Owens, et al. studied 272 pregnancies during a 6-year period. Pregnancy outcomes were compared from 2005-2007 to $2008-2010$. There were 272 pregnancies which were examined (61\% type 1 diabetic and 39\% type 2 diabetic). During the first period of the study $41 \%$ women received folic acid and during the second $62 \%$ received folic acid. There was an overall non-significant increase in the number of women receiving folic acid during pregnancy.

Similarly, Temple, et al. [17] showed that women who were not attending pre-pregnancy care were less likely to be taking folic acid (although data was not provided). All women in the study were advised to take folic acid supplementation before or as soon as they discontinued contraception. Women who had not received any preconception care were unlikely to have been receiving folic acid supplementation.

Tripathi, et al. [14] studied 588 women and 448 (76\%) had type 1 diabetes. There were 297 women of the 588 who did not receive preconception care. There were also 297 women who did not receive folic acid preconception. In comparison to this, preconception care was significantly associated with folic acid being taken within 3 months' preconception. There were 134 (68.4\%) women who were receiving preconception care that took folic acid within 3 months of preconception in comparison to $62(31.6 \%)$ women who were not receiving preconception care.

Murphy, et al. [19] found that 157/178 (88.2\%) women attending preconception care took folic acid during the preconception period in comparison to $112 / 420 \quad(26.7 \%)$ women who did not attend preconception care. However, Holmes, et al. [15] found that 47/111 (42.3) women pre-intervention were taking $5 \mathrm{mg}$ folic acid preconception in comparison to 65/134 (48.5) women who were post intervention. 


\section{Diabetes and Obesity International Journal}

Theme 3-Attendance to Preconception Care: All studies included elements of preconception care including advice on intake of folic acid, glycemic control and preconception counseling. Each study then measured congenital malformation rates in order to make a sound comparison to evaluate the effectiveness of the preconception care provided.

Callec, et al. [16] found that preconception care was effective in 4 out of 97 pregnancies. A total of 97 women with type 2 diabetes were included in the study and compared to the general population. There were 6 congenital malformations which was 3 times higher than the general population. Although despite this, no congenital malformations were found in fetuses of planned pregnancies. Overall preconception care was effective in only 4 out of 97 pregnancies.

Temple, et al. [17] studied 290 pregnancies in a prospective observational cohort study between 19911996 and 1997-2002. There were 110 (38\%) women who attended pre-pregnancy care. Women attending the care were seen 1-3 months by the consultant physician and also the diabetes specialist nurse. During the two study periods the mean age of women attending preconception care was 29.4 vs 28.6 years old.

There was also an association between accessing preconception care and a reduced risk of spontaneous abortion. However, data on socioeconomic status of participants was not collected and this was recognized as a potential factor in women seeking preconception care. Although overall the study showed a positive relationship between preconception care and maternal/fetal outcomes.

Although a prospective evaluation by Owens, et al. [18] found that the number of women attending preconception care increased in the period of 6 years, Tripathi, et al. [14] found a positive relationship between preconception care and pregnancy outcomes. However, half of the participants in the study did not receive preconception care. In addition to this, the study also recognized that positive outcomes of pregnancy may not be entirely linked to women receiving preconception care as women who actively seek help are likely to be more cautious of their health.

Murphy, et al. [19] found that there was a clear difference in pregnancy outcomes in women attending preconception care services in comparison to those who did not. The rates of malformations, stillbirths and perinatal mortality occurred in no more than 2 pregnancies. This number was more than double in women who did not receive in preconception care. Holmes, et al. [15] decided to provide preconception care through an educational DVD via primary care and secondary care practitioners. The rate of congenital malformation and awareness of how to maintain a healthy pregnancy were higher in the post DVD group in comparison to pre DVD.

\section{Study Characteristics}

The characteristics of each study have been discussed in relation to outcomes measured, interventions, participants, methods/design and their quality.

\section{Participants}

The nature of this study meant only women and babies were included. The number of participants ranged from 100 to 680 . Many of these were recruited from pre-pregnancy/perinatal care clinics, regional maternity survey centres as well as maternity departments in hospitals. The highest number of participants came from the pre-pregnancy clinics and the lowest came from the hospitals. The participants were recruited using an inclusion/exclusion criterion which involved the type of diabetes they were diagnosed with and whether they were receiving preconception care. The criteria did not state a specific age however it just stated that women should be of child bearing age with pre-gestational diabetes.

\section{Interventions}

The included studies used interventions which explored medical and social aspects of preconception care concerning women and the fetus. Many of the interventions took place over a prolonged period which varied from one year to eleven years. All of the studies involved women who were receiving or not receiving preconception care and their pregnancy was evaluated using the main themes; HbA1c level in the first trimester, attendance to preconception care and intake of folic acid.

\section{Outcome Measures}

The primary outcome of the systematic review was to evaluate the effectiveness of preconception care in women with type 1 and/or type 2 diabetes. The key themes gained from the outcomes as a whole were glycaemic control and the number of women who maintained an acceptable HbA1c level $(<7 \%)$ within 3 months of the first trimester. It also included the number of women who attended preconception care services, the number of women taking folic acid and the social demographics of the participants. These outcomes described were measured through surveys, audits and observations in the included studies. It is important to appreciate that these outcome measures will be used to evaluate how effective preconception care is in reducing maternal and foetal mortality and morbidity. 


\section{Diabetes and Obesity International Journal}

\section{Risk of Bias}

The matrix illustrated in table 6 shows the overview of the risk of bias in the studies. The table helps to reflect the rationale for the risk of bias in further depth.

\begin{tabular}{|c|c|c|}
\hline Author(s) and year of publication & Title of publication & $\begin{array}{l}\text { Risk of bias } \\
\text { (out of 6) }\end{array}$ \\
\hline $\begin{array}{c}\text { Tripathi A, Rankin J, Aarvold J, Chandler C } \\
\text { and Bell R (2010) [14] }\end{array}$ & A population based study in the North of England & 4 \\
\hline $\begin{array}{c}\text { Holmes VA, Hamil LL, Alderdice FA, Spence } \\
\text { M, Harper R, Patterson CC, Loughridge S, Mc } \\
\text { kenna S, Gough A and McCance DR (2016) } \\
\text { [15] }\end{array}$ & $\begin{array}{l}\text { Effect of implementation of a preconception } \\
\text { counselling resource for women with diabetes: A } \\
\text { population based study. }\end{array}$ & 4.5 \\
\hline $\begin{array}{l}\text { Temple RC, Aldridge JV and Murphy HR } \\
\text { (2006) [16] }\end{array}$ & $\begin{array}{c}\text { Pre-pregnancy care and pregnancy outcomes in } \\
\text { women with type } 1 \text { diabetes. }\end{array}$ & 4.5 \\
\hline $\begin{array}{l}\text { Owens LA., Carmody L, Avalos G, Dunne F } \\
\text { and Kirwan B (2012) [17] }\end{array}$ & $\begin{array}{l}\text { A change in clinical practice can improve outcomes } \\
\text { for women with pre-gestational diabetes. }\end{array}$ & 4.5 \\
\hline $\begin{array}{l}\text { Callec R, Perdriolle-Galet, Sery GA and } \\
\text { Morel O (2014) [18] }\end{array}$ & $\begin{array}{l}\text { Type } 2 \text { diabetes in pregnancy: Rates of fetal } \\
\text { malformations and level of preconception care. }\end{array}$ & 3.5 \\
\hline $\begin{array}{c}\text { Murphy H, Roland JM, Skinner TC, Simmons } \\
\text { D, Gurnell E, Mrrish NJ, Soo SC, Kelly S, Boon } \\
\text { L, Randall J, Thompsett S and Temple RC } \\
\text { (2010) [19] }\end{array}$ & $\begin{array}{c}\text { Effectiveness of a regional pre-pregnancy care } \\
\text { program in women with type } 1 \text { and type } 2 \text { diabetes: } \\
\text { benefits beyond glycaemic control. }\end{array}$ & 3 \\
\hline
\end{tabular}

Table 6: Table to show a summary of the overall quality of each included study - risk/bias matrix.

\begin{tabular}{|c|c|c|c|c|c|c|}
\hline \multicolumn{7}{|l|}{ Owens, 2012 [18] } \\
\hline \multicolumn{7}{|l|}{ Temple, 2006 [17] } \\
\hline \multicolumn{7}{|l|}{ Tripathi ,2010 [14] } \\
\hline \multicolumn{7}{|l|}{ Callec, 2014 [16] } \\
\hline \multicolumn{7}{|l|}{ Holmes, 2016 [15] } \\
\hline \multicolumn{7}{|l|}{ Murphy, 2010 [19] } \\
\hline & $\begin{array}{c}\text { Random sequence } \\
\text { generation }\end{array}$ & $\begin{array}{c}\text { Allocation } \\
\text { concealment }\end{array}$ & $\begin{array}{l}\text { Blinding of } \\
\text { assessment } \\
\text { outcome }\end{array}$ & $\begin{array}{c}\text { Blinding of data } \\
\text { analysis }\end{array}$ & $\begin{array}{c}\text { Incomplete } \\
\text { data }\end{array}$ & $\begin{array}{l}\text { Selective } \\
\text { reporting }\end{array}$ \\
\hline
\end{tabular}

Key: UR = unclear risk $\quad \mathrm{LR}=$ low risk

HR=high risk

\begin{tabular}{|c|c|c|c|c|c|c|}
\hline $\begin{array}{c}\text { First } \\
\text { author, } \\
\text { year }\end{array}$ & $\begin{array}{c}\text { Random } \\
\text { sequence } \\
\text { generation }\end{array}$ & $\begin{array}{c}\text { Allocation } \\
\text { concealment }\end{array}$ & $\begin{array}{c}\text { Blinding of } \\
\text { outcome } \\
\text { assessment }\end{array}$ & $\begin{array}{c}\text { Blinding of } \\
\text { data } \\
\text { analysis }\end{array}$ & $\begin{array}{c}\text { Incomplete } \\
\text { outcome } \\
\text { data } \\
\text { addressed }\end{array}$ & $\begin{array}{c}\text { Selective data } \\
\text { reporting }\end{array}$ \\
\hline $\begin{array}{c}\text { LR: Data was } \\
\text { obtained from a } \\
\text { national approved } \\
\text { pregnancy survey } \\
(2010) \\
\text { which reflected an } \\
\text { audit of }\end{array}$ & $\begin{array}{c}\text { LR: Women } \\
\text { were studied } \\
\text { after their } \\
\text { pregnancies } \\
\text { complicated with } \\
\text { diabetes. }\end{array}$ & $\begin{array}{c}\text { UR: There was } \\
\text { insufficient } \\
\text { information as } \\
\text { to whether the } \\
\text { participant was } \\
\text { blinded. }\end{array}$ & $\begin{array}{c}\text { Although } \\
\text { statistical } \\
\text { analysis was } \\
\text { used it was } \\
\text { unclear as to } \\
\text { whether the } \\
\text { researcher. }\end{array}$ & $\begin{array}{c}\text { LR: All data } \\
\text { was } \\
\text { acounted } \\
\text { for. }\end{array}$ & $\begin{array}{c}\text { LR: The } \\
\text { relevant } \\
\text { information provided in } \\
\text { whe form of } \\
\text { tables. }\end{array}$ \\
\hline
\end{tabular}




\begin{tabular}{|c|c|c|c|c|c|c|}
\hline $\begin{array}{c}\text { Holmes } \\
(2016) \\
{[15]}\end{array}$ & $\begin{array}{l}\text { LR: All women } \\
\text { attending twelve } \\
\text { tertiary perinatal } \\
\text { centres with type } \\
\text { one or two } \\
\text { diabetes were } \\
\text { included }\end{array}$ & $\begin{array}{c}\text { UR: There } \\
\text { was } \\
\text { insufficient } \\
\text { information } \\
\text { as to whether } \\
\text { participants } \\
\text { were } \\
\text { randomly } \\
\text { allocated }\end{array}$ & $\begin{array}{l}\text { UR: It was not } \\
\text { clear as to } \\
\text { whether the } \\
\text { participants } \\
\text { were blinded to } \\
\text { the outcomes. }\end{array}$ & $\begin{array}{l}\text { UR: It was } \\
\text { unclear as to } \\
\text { whether } \\
\text { analysis was } \\
\text { done } \\
\text { blinded. }\end{array}$ & $\begin{array}{l}\text { LR: All } \\
\text { information } \\
\text { was } \\
\text { provided. }\end{array}$ & $\begin{array}{l}\text { LR: Data was } \\
\text { shown in the } \\
\text { form of tables }\end{array}$ \\
\hline $\begin{array}{c}\text { Callec } \\
(2012) \\
{[16]}\end{array}$ & $\begin{array}{l}\text { LR: All women } \\
\text { who attended } \\
\text { university hospital } \\
\text { information were } \\
\text { included and the } \\
\text { control group data } \\
\text { was obtained from } \\
\text { the most recent } \\
\text { French perinatal } \\
\text { survey. }\end{array}$ & $\begin{array}{l}\text { UR: There is } \\
\text { lack of } \\
\text { information } \\
\text { regarding the } \\
\text { allocation } \\
\text { concealment } \\
\text { for the } \\
\text { included } \\
\text { participants. }\end{array}$ & $\begin{array}{l}\text { HR: The study } \\
\text { had an } \\
\text { observational } \\
\text { nature. }\end{array}$ & $\begin{array}{l}\text { HR: The } \\
\text { researchers } \\
\text { performed } \\
\text { statistical } \\
\text { analysis un- } \\
\text { blinded. }\end{array}$ & $\begin{array}{l}\text { LR: Any } \\
\text { incomplete } \\
\text { data was } \\
\text { accounted } \\
\text { for. }\end{array}$ & $\begin{array}{l}\text { LR: Outcome } \\
\text { data appeared } \\
\text { to be complete } \\
\text { and accurate. }\end{array}$ \\
\hline $\begin{array}{c}\text { Temple } \\
(2006) \\
{[17]}\end{array}$ & $\begin{array}{l}\text { LR: Women who } \\
\text { attended a } \\
\text { antennal clinic and } \\
\text { had type one } \\
\text { diabetes were } \\
\text { recruited. }\end{array}$ & $\begin{array}{l}\text { LR: Statistical } \\
\text { analysis and } \\
\text { tests was } \\
\text { used to } \\
\text { interpret the } \\
\text { results. }\end{array}$ & $\begin{array}{l}\text { UR: There was } \\
\text { lack of } \\
\text { information } \\
\text { regarding the } \\
\text { blinding of } \\
\text { outcomes. }\end{array}$ & $\begin{array}{l}\text { UR: There } \\
\text { was } \\
\text { insufficient } \\
\text { information } \\
\text { regarding } \\
\text { blinding. }\end{array}$ & $\begin{array}{l}\text { LR: All } \\
\text { information } \\
\text { was } \\
\text { accounted } \\
\text { for. }\end{array}$ & $\begin{array}{l}\text { UR: No tables } \\
\text { were provided } \\
\text { however } \\
\text { statistical data } \\
\text { was provided in } \\
\text { written } \\
\text { communication. }\end{array}$ \\
\hline $\begin{array}{c}\text { Owens } \\
(2012) \\
{[18]}\end{array}$ & $\begin{array}{l}\text { UR: “All women } \\
\text { with diabetes for } \\
\text { less than } 6 \text { months } \\
\text { were included } \\
\text { who attended an } \\
\text { ATLANTIC DIP } \\
\text { clinic during } \\
\text { (2005-2008) }\end{array}$ & $\begin{array}{l}\text { UR: Lack of } \\
\text { information } \\
\text { regarding } \\
\text { process of } \\
\text { allocation. }\end{array}$ & $\begin{array}{l}\text { LR: Women } \\
\text { were studied } \\
\text { after having } \\
\text { preconception } \\
\text { care. }\end{array}$ & $\begin{array}{c}\text { UR: } \\
\text { Insufficient } \\
\text { information } \\
\text { regarding } \\
\text { data } \\
\text { analysis. }\end{array}$ & $\begin{array}{l}\text { LR: All data } \\
\text { was } \\
\text { provided. }\end{array}$ & $\begin{array}{l}\text { LR: Tables of } \\
\text { data were } \\
\text { provided for } \\
\text { both study } \\
\text { periods. }\end{array}$ \\
\hline $\begin{array}{c}\text { Murphy } \\
(2016) \\
{[19]}\end{array}$ & $\begin{array}{c}\text { UR: Women } \\
\text { attending } \\
\text { antenatal clinics } \\
\text { were registered as } \\
\text { part of the study, } \\
\text { however no clear } \\
\text { inclusion criteria } \\
\text { was stated. }\end{array}$ & $\begin{array}{l}\text { UR: There } \\
\text { was a lack of } \\
\text { information } \\
\text { regarding any } \\
\text { time of } \\
\text { allocation in } \\
\text { the study. }\end{array}$ & $\begin{array}{l}\text { UR: It was } \\
\text { unclear as to } \\
\text { whether } \\
\text { participants } \\
\text { were blinded } \\
\text { from the study } \\
\text { outcomes. }\end{array}$ & $\begin{array}{c}\text { UR: } \\
\text { Although } \\
\text { statistical } \\
\text { analysis } \\
\text { systems } \\
\text { were used, it } \\
\text { was unclear } \\
\text { as to } \\
\text { whether } \\
\text { there was } \\
\text { blinding. }\end{array}$ & $\begin{array}{l}\text { LR: All } \\
\text { information } \\
\text { was } \\
\text { provided. }\end{array}$ & $\begin{array}{l}\text { LR: Data was } \\
\text { provided in the } \\
\text { form of tables }\end{array}$ \\
\hline
\end{tabular}

Table 7: Table to show the rationale for risk of bias in each study (UR= unclear risk, $L R=$ low risk, HR = high risk).

\section{Discussion}

This systematic review assessed six studies and the effectiveness of preconception care in type 1 and type 2 diabetic women. This chapter aims to discuss some of the strengths and limitations of the included studies and methodological challenges faced.

\section{Glycaemic Control}

All included studies except one [16] assessed HbA1c levels in comparison to the level of preconception care received by women. In this review, the results were overall moderately unbiased and therefore any heterogeneity may be due to a difference in participants or interventions. 


\section{Diabetes and Obesity International Journal}

One of the included studies [17] showed significant improvement between glycaemic control and preconception care. The results showed $62 \%$ of women in the intervention group achieving a mean $\mathrm{HbA1c}<7 \%$ vs $35.4 \%$ in the group not receiving preconception care. The intervention in the study included physician and specialist nurse visits every 1-3 months and patients were educated on the risk of hypo/hyperglycaemia during pregnancy. This study demonstrated the highest improvement rate in glycaemic control in comparison to the other five. However, the number of participants was in a median range (290 women) in this study [19] and the lowest being 97 women in Callec, et al. [16]. Therefore, due to a good sample size, a single improvement in a participant's HbA1c is likely to have been well reflected in the results. Another reason for the improvement rate may be due to the multidisciplinary approach adopted in the study. Women were assessed from a well-rounded point of view. For example, physicians would advise patients on their medical treatment and nurses would educate patients in more detail on how to adjust to a healthier lifestyle.

Temple, et al. [17] conducted their study over an 11year period and this study was of the longest duration in relation to the other five studies. Therefore, they obtained more than just a 'snapshot' of preconception care and could be the reason for such high improvement rates. Tripathi, Rankin, Aarvold, et al. [13] had the second highest improvement rate in glycaemic control (55.4\% of women achieving a mean HbA1c $<7 \%$ in women who received preconception care vs $44.6 \%$ to those who did not receive preconception care). However it is important to note that Tripathi, et al. [14] had data missing regarding HbA1c levels for 277 women. This accounted for $47 \%$ of the sample size.

Owens, et al. [18] examined 272 women and found an improvement rate in glycaemic control after implementing a change in practice involving more specialist hub led care. The overall mean HbA1c level decreased from $7.3 \%$ to $6.9 \%$ in participants between the two study periods (2005-2007 and 2008 to 2010). Murphy, et al. [19] showed an improvement rate in glycemic control with $53 \%$ of women receiving preconception care achieving a mean $\mathrm{HbA} 1 \mathrm{c}<7 \%$ vs $77 \%$ to those without preconception care. One reason behind this result could be due to Murphy, et al. investigating a range of maternity centres in one region. Therefore this may have enabled more women to be.

Holmes, Hamill, Alderdice, et al. [15] showed a very little improvement rate (less than 5\% difference in results of mean $\mathrm{HbA} 1 \mathrm{c}$ between the intervention and control group) in glycaemic control. The overall difference in glycaemic control between the two groups was not as significant (a mean HbA1c of $7.4 \%$ in the intervention group vs $7.3 \%$ in the group with no intervention). This could be due to DVD's not is being viewed till the end or important parts being skipped.

To summarise each of the five studies show a mixed range of improvement in glycaemic control. However, only one study showed very little improvement [15]. Most of the studies showed at least some improvement. Therefore this could potentially emphasise that the effectiveness of preconception care is dependent on the method in which it is delivered. Moreover making comparisons on the improvement of HbA1c levels between studies proved difficult due to the number of participants and methods of preconception care delivery varying between studies.

The optimisation of glycaemic control in preconception care is associated with improved pregnancy outcomes for both the mother and baby. It has been emphasised that glycaemic control can reduce the risk of miscarriage, congenital malformations, stillbirths and neonatal deaths (NICE guidelines, 2015). Three of the included studies in this review help to reflect this. They help to reinforce the importance of early intervention in controlling HbA1c levels during pregnancy. Temple, et al. [17] found that 23 of the participants not receiving preconception care had preeclampsia compared to only 14 women who did receive preconception care.

This reinforces the value of a multidisciplinary team approach in preconception care. For instance, a consultation with a specialist doctor will provide patients with the knowledge required for a healthy pregnancy. However, this can be complimented with a consultation with a specialist nurse for wider issues such as diet, lifestyle and monitoring glycaemic control to be discussed in detail. To further support this, Owens, et al. [18] found that that only $21.2 \%$ of women had suffered from a miscarriage; the difference in the rate of miscarriages between the two groups was $17.2 \%$. It was found that 22 women not receiving preconception care had experienced a miscarriage compared to 8 women who did receive it. This helps to reinforce the value multidisciplinary care can have upon patients. A study by Holmes, et al. [15] using DVD's to educate patients, showed the number of women experiencing miscarriages decreased from $14 \%$ to $4 \%$. As a result, this helps to expand on the importance of multidisciplinary team and introduces the concept of using different methods to communicate clinical information with patients.

Callec, et al. [16] assessed the rate of congenital malformations in babies from type 2 diabetic mothers and could not show a definitive positive link between glycaemic control and reducing congenital malformations. However this study focused only on type 2 diabetic women and therefore the level of improvement could have been proven positive if type 1 


\section{Diabetes and Obesity International Journal}

diabetic women were included. Similarly, Temple, et al. [17] found that type 1 diabetic women had better pregnancy outcomes after increased glycaemic control in their first trimester. This implies that type 2 diabetic women are less aware of the importance of glycaemic control in relation to type one diabetic patients. Tripathi, et al. [14] found that only 1 out of 152 pregnancy outcomes resulted in a congenital malformation from the preconception care group. This study included women of type 1 and type 2 diabetes, therefore the results can be generalised to the whole population. To further support these Murphy, et al. [19] found that 39 out of 535 women not receiving preconception care had babies with congenital malformations in comparison to 24 out of 462 with women who did receive preconception care. However, this study did certainly show a decrease in type 2 diabetic women having babies with congenital malformations (4.5\% from $12.3 \%)$. Owens, et al. [18] found that the number of malformations went down from 22 to 8 across two study periods in women receiving preconception care. This finding once again strongly implies that effective pre-conception care will result in better glycaemic control and ultimately lead to positive maternal and neonatal outcomes.

The Kings Fund [20] report noted that there are growing demographic changes in society and as a result patients are presenting with complex medical and psychosocial needs. It has been emphasised for the need of technology to be further incorporated in healthcare to educate patients. Technology can be defined as any resource that involves an aspect of information being delivered through a computed or interactive system [20]. The report reflects the key impacts technology has on improving healthcare. These include: providing patients with easy to access information on support and self-care, encouraging patient engagement and facilitating improved continuity of care. However of course, there is a disadvantage that follows with the use of technology; not all patients will be able to use technology or have access to certain technology. Patients may prefer or even require medical jargon to be explained to them in more detail face to face to prevent misinterpretation. Given the results of this review, it may be appropriate to state that, technology should be used as an adjunct to encourage patients to attend preconception care clinics rather than solely be used to educate patients.

\section{The Intake of Folic Acid}

The intake of $5 \mathrm{mg}$ folic acid preconception and during the first 12 weeks of pregnancy has been linked to a decreased risk of congenital malformations. Three studies show an improvement in the number of women who took folic acid if they had received preconception care. Owens, et al. [18] found a low improvement rate in women taking folic acid after preconception care $(41 \%$ in the preconception care group vs $62 \%$ in the no preconception care group). Two studies did not investigate folic acid $[16,17]$.

Murphy, et al. [19] researched 10 different regional preconception care centres (including women with type 1 and type 2 diabetes) and found the highest number (88.2\%) of women taking folic acid. One advantage of this prospective cohort study is that the use of 10 regional centres reduced the risk of selection bias. Holmes et al. [15] demonstrated the second highest rate of women taking folic acid preconception and during pregnancy ( $81 \%$ of the intervention group). One of the strengths of this study is that it took place in a primary care setting and therefore it may have been easily accessible for women. The use of an electronic resource helps to educate a larger number of participants than just clinics alone. In addition, patients can access information in a time and place that is convenient to them. Similarly, Tripathi, et al. [14] found the third highest number of women taking folic acid (68\% of the intervention group). This study compared data from many different maternity centres in one region and therefore also targeted a wider range of participants. It is important to note that although a multitude of maternity centres were compared, each centre may have differing protocols on their delivery of preconception care; ultimately, this can impact the generalisability of the findings.

Owens, et al. found the lowest number of women taking the supplement $(41 \%$ from the preconception care group vs $62 \%$ in the group not receiving any intervention). One reason for the reduced uptake of women taking folic acid in this study compared to other studies may be due to the fact that women were taking the lower dose at 500 micrograms. A dose at this strength is available without a prescription and therefore if an adequate medical history is not taken by a clinician, then this information may not be documented in the medical records. Therefore, this difference in result does not necessarily mean that women were not taking the supplement at all. However, many of the patients in these studies were selfreporting whether they had taken the supplement and therefore an element of reported and recall bias must be considered. Subsequently, this method leaves space for uncertainty and error in interpreting the findings. It is important to mention that some patients may not be taking the non-prescription strength folic acid, but they may feel obliged to state that they are. This may be due to an expectation or some form of direct or indirect influence from the clinician. The patient may not be taking the folic acid for a whole host of reasons; to include the pharmacological side effects, any preconceptions they already have about the drug or they simple choose not to take it. It is also important to note that even if the medical records state that a patient is taking folic acid, it does not necessarily mean that the 


\section{Diabetes and Obesity International Journal}

patient is concordant with the medication regime. Therefore, there is no certainty that patients are taking folic acid regularly, which could lead to inaccurate conclusions being drawn about the effectiveness of it.

As stated earlier, the aim of folic acid supplementation is to reduce the risks of neural tube defects. However only one out of the six included studies [17] state that there were 6 neural tube defects in the babies whose mothers received preconception care; it did not state the figure of neural tube defects in women who had not received preconception care. Therefore this made it difficult to analyse the relationship between preconception care and neural tube defects. Neural tube defects are known as one of the most common malformations in neonates which occur in the early weeks of gestation [21]. They can significantly decrease the quality of life for a baby. The incidence varies from 12 per 1000 pregnancies in Ireland and Wales and Indian Sikhs in Egypt [21]. Diabetes in pregnant women is known to increase the incidence of neural tube defects [1]. One method to promote the importance of taking folic acid this could be to educate all women of child bearing age on the importance of taking the supplement when planning and during pregnancy. Local campaigns can also be implemented to raise awareness in women regarding the impacts of neural tube defects on babies. In addition, education about this can begin in science teaching in secondary schools.

Service users can also be involved in teaching healthcare professionals on how to work with women at a higher risk of delivering a baby with neural tube defects. A study by McGarry and Thom [20] showed student nurses had a positive experience of service user involvement in teaching. It also emphasised the value of practising person centred care to promote good health.

\section{The rate of attendance to preconception care clinics}

The number of women attending preconception varied amongst all six studies. Many of the women attending were of Caucasian, Irish or British ethnicity as shown by Holmes, et al., Murphy, et al. and Tripathi, et al. $[14,15,19]$. There was an exception of three studies which did not state the ethnic background of the women attending preconception care clinics [16-18]. It has been demonstrated that Caucasian, white British and Irish population attending preconception care represented the highest numbers in the studies compared to any other ethnic group $[14,15,19]$. Therefore, it could be argued as to whether other ethnicities have a lower rate of attendance to preconception care clinics due to socioeconomic and cultural barriers. One of the causes behind these barriers is low health literacy. Health literacy refers to a person's ability to access and understand information regarding their health [23]. Low health literacy can be influenced by factors such as socio-economic position, culture and language and the educational status of a patient [23]. A low level of health literacy may result in patients being unable to manage their health effectively or access healthcare services. The rapid estimate of adult literacy in medicine (REALM) is used to assess a patient's [24] health literacy status. However this tool fails to consider patient attitude, values and beliefs [21]. These findings raise the question of whether care is being individualised and person centred for women with specific social and cultural backgrounds. Therefore, future research in developing this assessment tool further may prove valuable.

Holmes, et al. [15] used a DVD to educate women on maintaining a healthy pregnancy. The study had data missing regarding many pregnancy outcomes such as congenital anomalies, stillbirth and neural tube defect rates. However it proves to be useful in providing insight in promoting health. Therefore one of the alternatives to address health inequalities may be to collaborate multidisciplinary care clinics alongside complimentary resources (which are available in all languages). Shared decision making may also prove useful in preconception care [25]. This will help women make more informed decisions about the care and ultimately allow patient autonomy.

Murphy, et al. [19] found that the women not attending preconception care were the most socially deprived. Each participant was categorised in quantiles ranging from 1-4 (4 being the most deprived). One of the strengths of this study is that it included both type 1 and type 2 diabetic women, making it generalisable to all women with diabetes. Moreover, it also implemented the study over 10 different regional centres helping to reduce selection bias. Callec, et al. [16] found that preconception care was only effective in 4 out of 97 pregnancies in women with type 2 diabetes. This indicates the need for preconception care to be individualised. Although Temple, et al. [17] found there was no difference in social demographics between women accessing care earlier and later. They identified there was a strong need to encourage women to attend preconception care earlier. Owens, et al. [18] further supported this by stating that earlier glycaemic control helped to reduce the risk of delivering an infant with macrosomia, risk of miscarriage and foetal malformations. This raises the importance of women understanding the value of attending preconception clinics earlier.

The use of technology in healthcare may prove to be useful in reaching out to socially disadvantaged women. Although this is not to say that current assisting resources such as patient information leaflets provided by doctors and specialist nurses [26] should be neglected. One of the limitations of the study included that it did not clearly state whether type 1 or type 2 
diabetic women benefited from structured preconception counselling.

Further to this Tripathi, et al. [14] stated that preconception care may not be the sole factor in improving pregnancy outcomes. It was demonstrated that patient motivation could also be a factor in particularly for type 2 diabetic women. Therefore, this helps to reinforce the idea of whether healthcare providers (particularly primary care services) need to alter preconception care services to attract type 2 diabetic women and alter their way of thinking. It also highlights the importance of gathering information such as hidden agendas carefully from patients; this can be through the Cambridge-Calgary consultation skills model whereby patient ideas, concerns and expectations are gathered [27]. This model also focuses strongly on nonverbal communication and being aware of recognising, acknowledging and validating patient concerns [27].

Gross and Kinnison [28] cited the protection motivation theory by Rogers (1975) which helps to identify potential reasons why women do not access services to help their health. It shows how fear may influence women in changing health behaviours. The model summarises the concept of efficacy of health behaviour (response efficacy) and the amount of confidence a women may have to carry out an action (self-efficacy) against the risks and benefits of it [28]. The concept of self-efficacy is a key component of this model as it helps to reflect motivation in changing health behaviours. For instance, low self-efficacy would help to reflect why women do not access healthcare services. For instance acknowledging their pregnancy could have risks may result in them experiencing stress and anxiety. As a result this may discourage women in accessing preconception services. However the national service framework for diabetes set by the Department of Health (2001) [29] states that the aim of maternity care is to ensure all pregnant women have a positive experience of their pregnancy that promotes physical and psychological health. It also acknowledges that some women experiencing constant 'medicalised' care may feel less encouraged about their pregnancy.

\section{Conclusion}

The purpose of this research was to assess the effectiveness of preconception care in type 1 and type 2 diabetic women. A thorough systematic approach and a comprehensive literature search was used to do this. The findings from the six studies included in this review were analysed in a thematic format, similar to those themes found in the studies. These themes included; glycaemic control, intake of folic acid and the rates of attendance/participation in preconception care.
It is suggested that while preconception care is effective, the manner in which it is delivered is what determines the extent of its effectiveness. For future research qualitative data using semi-structured interviews may prove to be useful to analyse the lived experience of women partaking in preconception care. It would also provide the opportunity to understand how care can be person centred to meet individual needs based on socio-economic and cultural factors. This may help to provide better access to preconception care in the form of clinics, electronic resources and out of hour's services. Although many of the studies had statistically relevant results, it does not mean they are clinically relevant. Therefore, the results of this review should be applied to practice with caution.

Further research is also required on how preconception care can be delivered to women with specific needs, such as language requirements, intellectual ability and varying socio-cultural backgrounds. Every woman is different in her own unique way. Every woman will have a very specific need. Each woman deserves person centred care.

\section{Reference}

1. National Institute for Health and Care Excellence (2015) Diabetes in pregnancy: management from preconception to the postnatal period.

2. Hod M, Jovanovic L, Di Renzo G, Leiva A, Langer 0 (2016) Textbook of diabetes and pregnancy. 3rd (Edn.), CRC press, Boca Raton.

3. Langer $O$ (2015) The diabetes in pregnancy dilemma. 1st (Edn.), Peoples Medical Publishing House, China.

4. World Health Organisation (WHO) (2016) WHO recommendations on interventions to improve preterm birth outcomes.

5. Torjesen I (2015) Premature births are blamed for high death rate in UK's under 5s compared with Sweden. BMJ 351: h4406.

6. Behrman R, Butler A (2007) Preterm birth. 1st (Edn.), National Academies Press, Washington DC.

7. King P (2013) A new model for preconception care in women with diabetes. Journal of Diabetes Nursing 17(2): 56-61.

8. Tsatsoulis A, Brown F, Wyckoff J (2010) Diabetes in Women. 1st (Edn.), Humana Press, New Jersey.

9. Chew S, Leslie R (2006) Clinical endocrinology and diabetes. 1st (Edn.), Churchill Livingstone, Edinburgh. 


\section{Diabetes and Obesity International Journal}

10. Confidential Enquiry into Maternal and Child Health (CEMACH) (2004) Maternity Services in 2002 for Women with Type 1 and Type 2 Diabetes. London: Royal College of Obstetrics and Gynaecologist's.

11. Mills L, Palmer C, Arya R (2015) Reducing diabetesrelated complications in pregnancy. British Journal of Midwifery 23(12): 848-853.

12. Higgins J, Green S (2011) Cochrane Handbook for Systematic Reviews of Interventions Version 5.1.0. The Cochrane Collaboration.

13. Moher D, Liberati A, Tetzlaff J, Altman D, The PRISMA Group (2009) Preferred Reporting Items for Systematic Reviews and Meta-Analyses: The PRISMA Statement. PLoS Medicine 6(7): e1000097.

14. Tripathi A, Rankin J, Aarvold J, Chandler C, Bell R (2010) A population based study in the North of England. American Diabetes Care Journal 33(3): 586-588.

15. Holmes VA, Hamil LL, Alderdice FA, Spence M, Harper R, et al. (2016) Effect of implementation of a preconception counselling resource for women with diabetes: A population based study. Prim Care Diabetes 11(1): 37-45.

16. Callec R, Perdriolle-Galet, Sery GA, Morel O (2014) Type 2 diabetes in pregnancy: Rates of fetal malformations and level of preconception care. Journal of Obstetrics and Gynaecology 34(7): 648649.

17. Temple RC, Aldridge JV, Murphy HR (2006) Prepregnancy care and pregnancy outcomes in women with type 1 diabetes. American Diabetes Care Journals 29(8): 1744-1749.

18. Owens LA, Carmody L, Avalos G, Dunne F, Kirwan B (2012) Change in clinical practice can improve outcomes for women with pre-gestational diabetes. American Diabetes Care Journal 35(8): 1669-1671.

19. Murphy H, Roland JM, Skinner TC, Simmons D, Gurnell E, et al. (2010) Effectiveness of a regional prepregnancy care program in women with type 1 and type 2 diabetes: benefits beyond glycaemic control. American Diabetes Care Journal 33(12): 2514-2520.

20. The Kings Fund (2008) Safe births: Everybody's business.

21. World Health Organisation (WHO) Prevention of neural tube defect rates.

(2009)

22. McGary J, Thom N (2004) How users and carer's view their involvement in nurse education. Nursing times 100(18): 36-39.

23. Batterham RQ, Hawkins M, Collins PA, Buchbinder R, Osborne RH (2016) Health literacy: applying current concepts to improve health services and reduce health inequalities. Public health 132: 30-12.

24. Agency for Healthcare research and quality (2016) Health Literacy Measurement Tools.

25. Stacey D, Murray M, Legare F, Sandy D, Menar P, et al. (2008) Decision Coaching to Support Shared Decision Making: A Framework, Evidence, and Implications for Nursing Practice, Education, and Policy. Worldviews Evid Based Nurs 5(1): 25-35.

26. National Institute for Health and Care Excellence (2015) Type 1 diabetes in adults: diagnosis and management.

27. Moulton L (2007) The Naked Consultation: A Practical Guide to Primary Care Consultation Skills. Radcliffe publishing Ltd, Oxon.

28. Gross R, Kinnison N (2013) Psychology for Nurses and Health Professionals. 2nd (Edn.), CRC press, Boca Raton, pp. 531-589.

29. Department of Health (DH) (2001) National Service Framework for Diabetes. London: DH.

30. Moher D, Liberati A, Tetzlaff J, Altman D, The PRISMA Group (2009) Preferred Reporting Items for Systematic Reviews and Meta-Analyses: The PRISMA Statement. PLoS Medicine 6(7): e1000097. 